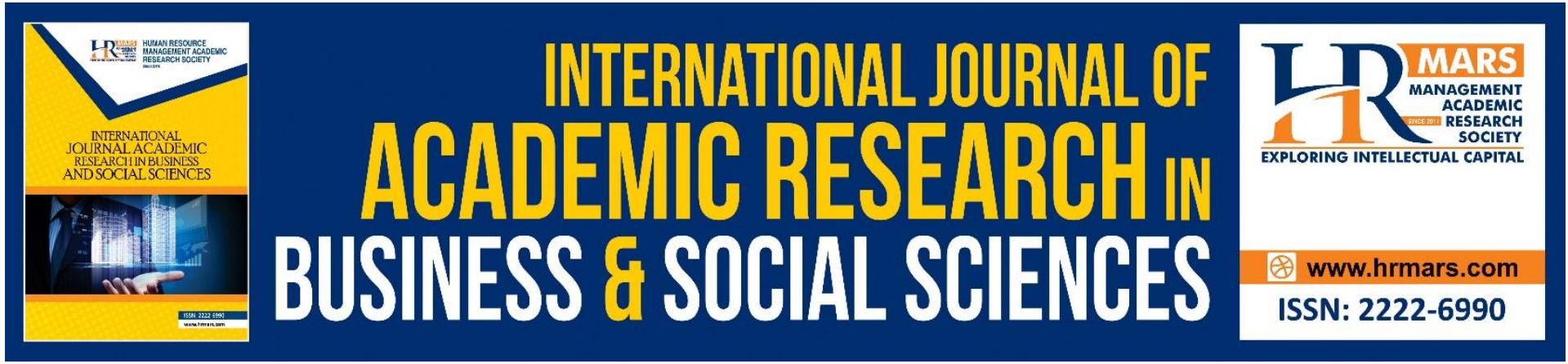

\title{
Factors that Influence the Inflation Rate in Malaysia
}

Najihah Yusof, Liya Fitrya Nin, Haida Kamelia Md Kamal, Jamilyn Rasyeeda Ahmad Taslim, Amir Imran Zainoddin

To Link this Article: http://dx.doi.org/10.6007/IJARBSS/v11-i9/10838

DOI:10.6007/IJARBSS/v11-i9/10838

Received: 06 July 2021, Revised: 28 July 2021, Accepted: 20 August 2021

Published Online: 16 September 2021

In-Text Citation: (Yusof et al., 2021)

To Cite this Article: Yusof, N., Nin, L. F., Kamal, H. K. M., Taslim, J. R. A., \& Zainoddin, A. I. (2021). Factors that Influence the Inflation Rate in Malaysia. International Journal of Academic Research in Business and Social Sciences, 11(9), 626-637.

Copyright: (c) 2021 The Author(s)

Published by Human Resource Management Academic Research Society (www.hrmars.com)

This article is published under the Creative Commons Attribution (CC BY 4.0) license. Anyone may reproduce, distribute, translate and create derivative works of this article (for both commercial and non-commercial purposes), subject to full attribution to the original publication and authors. The full terms of this license may be seen at: http://creativecommons.org/licences/by/4.0/legalcode

Vol. 11, No. 9, 2021, Pg. 626 - 637

Full Terms \& Conditions of access and use can be found at http://hrmars.com/index.php/pages/detail/publication-ethics 


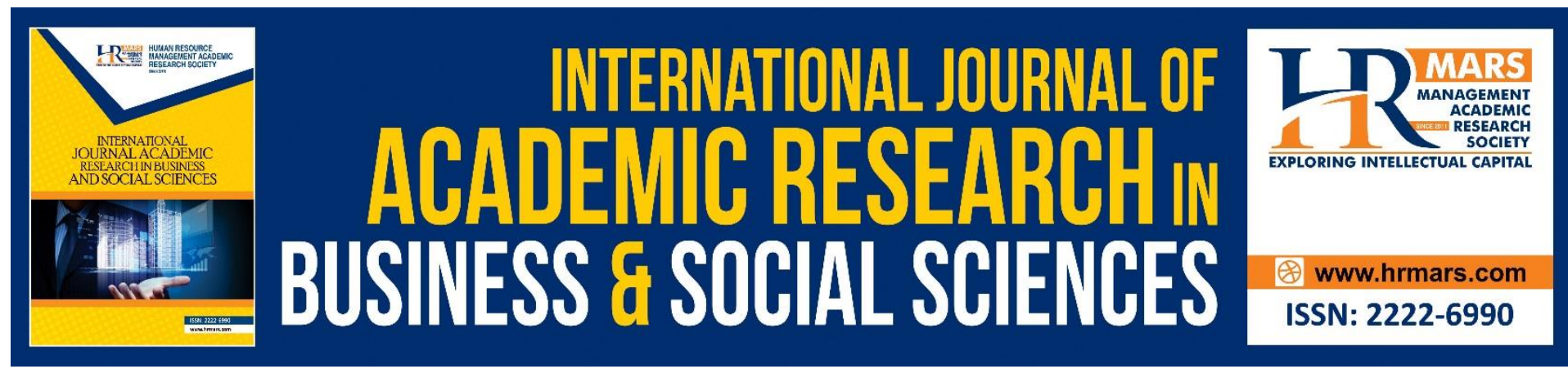

\title{
Factors that Influence the Inflation Rate in Malaysia
}

\section{Najihah Yusof, Liya Fitrya Nin, Haida Kamelia Md Kamal, Jamilyn Rasyeeda Ahmad Taslim, Amir Imran Zainoddin}

Faculty of Business and Management, Universiti Teknologi MARA Cawangan Johor, Kampus

Segamat, 85000 Segamat, Johor, Malaysia

Corresponding Author Email: amirimran@uitm.edu.my

\begin{abstract}
Maintaining a low and steady inflation rate has become one of the challenges in most nations. Many factors have contributed to Malaysia's inflation rate over the last few years, and it can be either economic or external factors. As only a few current studies have been discussed on this topic, this paper is primarily interested to examine the factors that affect the inflation rate in Malaysia from the year 1991 to 2020. The study also looks into whether the factors of inflation play a role in the changes in Malaysia's inflation rate. Hence, the independent variables that were chosen are economic growth (GDP), government expenditure (GE), exchange rate (ER) and unemployment rate (UNEMP), while the inflation rate (CPI) is the dependent variable. This paper utilized the Ordinary Least Squares (OLS) regression method to determine the significance of independent variables in causing inflation. The data for this study were collected during 30 years from the World Bank and Thomson Reuters DataStream. Overall, the results have found that ER, GE and UNEMP has a significant relationship with inflation in Malaysia. Interestingly, the study revealed that no significant relationship between economic growth and inflation during the period of study. Therefore, the outcome of this study implies that future research should employ the threshold model and Autoregressive Distributed Lag (ARDL) models approach to obtain accurate conclusions on the impacts of economic growth on inflation. In summary, this study will assist the policymaker and the government to control the inflation rate by tightening the monetary policy and implementing the fiscal policy.
\end{abstract}

Keywords: Inflation, Unemployment Rate, Government Expenditure, Exchange Rate, EconomicGrowth, Malaysia

\section{Introduction}

Inflation is a rise in the cost of goods and services purchased by households. Inflation is also known as the percentage rise in the Consumer Prices Index (CPI) from year to year (Marya et al., 2014). A high inflation rate means there will be a rise in the cost of the material. Still, lower inflation leads to slower economic growth and eventually will lead to recession and a high unemployment rate. Nevertheless, according to Munir and Mansur (2009), a lower inflation condition is essential for economic growth. 
According to Governor of Bank Negara Malaysia (BNM), Datuk Nor Shamsiah, the most significant influence on CPI in Malaysia is the exchange rate, led by crude oil prices, foreign debt, and indirect tax per capita. Moreover, BNM expects an inflation rate between $2.5 \%$ and $4 \%$ in 2021 , compared to negative inflation at $-1.2 \%$ in the previous year as the global crude oil and commodity prices recover.

Cheng and Tan (2002) found a significant impact between money supply and inflation rate. Inflation will happen when the money supply is increasing faster than the actual output growth. Ramayah (2016) also examined the factors that influence inflation in ASEAN countries, namely, Malaysia, Singapore, and Indonesia. His findings are consistent in those three countries. As the money supply increases, inflation levels also increase.

Moreover, according to previous research conducted by Maryam et al (2014), the interest is rate negatively correlated to inflation. According to current economic theory, rising interest rates slows the growth of the economy's aggregate demand, thus resulting in lower inflation (Egilsson, 2020). This theory is based on demand-pull inflation, which states that rising interest rates decrease consumer consumption and making saving a more attractive alternative.

Arinze (2011) used simple regression analysis, discovered that as the price of oil rises, the inflation rate increases as well; therefore, this indicates inflation and oil price had a positive relationship. Another study by Ramayah (2016) also discovers that oil price has a positive relationship with inflation in Malaysia. Hence, the consumer price index rises as the price of oil rises which will affect inflation.

\section{Background of Study}

One macroeconomic factor is inflation, and many developing countries are facing this economic issue. Inflation is the most crucial impact on economics, and one of any government's primary fiscal goals is to keep it controlled. Inflation is the rate of increase in the general price level of goods and services in the economy (Ramasamy and Abar, 2015). It can be connected to a depreciation in the dollar's value; hence consumers are prepared to buy less than they could previously (Mun et al., 2017).

The most well-known indicator of inflation is the Consumer Price Index, which is calculated by the per cent rise in the Consumer Price Index (CPI) from one year to the next. Therefore, $\mathrm{CPI}$ is a relevant and valuable indicator for the conduct of macroeconomics policies. Malaysia's annual inflation rate has consistently been around 2.9 per cent except for the last year (Islam et al., 2017).

Moreover, for the year 2020, the Malaysian inflation rate recorded was $-1.13 \%$. Malaysian Industrial Development Finance Berhad (MIDF) Research stated that Malaysia's last time deflation in CPI was in 1965, with a tepid fall of -0.1 per cent year-on-year. However, after a year of being in negative territory, Malaysia's headline inflation returned to a positive environment in February 2021, at 0.1 per cent year-on-year (YoY). 
Figure 1 shows the rate of inflation in Malaysia using the consumer price index from 1991 until 2020. From 1991 to 2019, Malaysia's average inflation rate stays between 1\% to 5\%. However, in 2020 , the inflation rate falls to $-1.13 \%$.

Figure 1: Malaysia's Consumer Price Index (annual, \%)

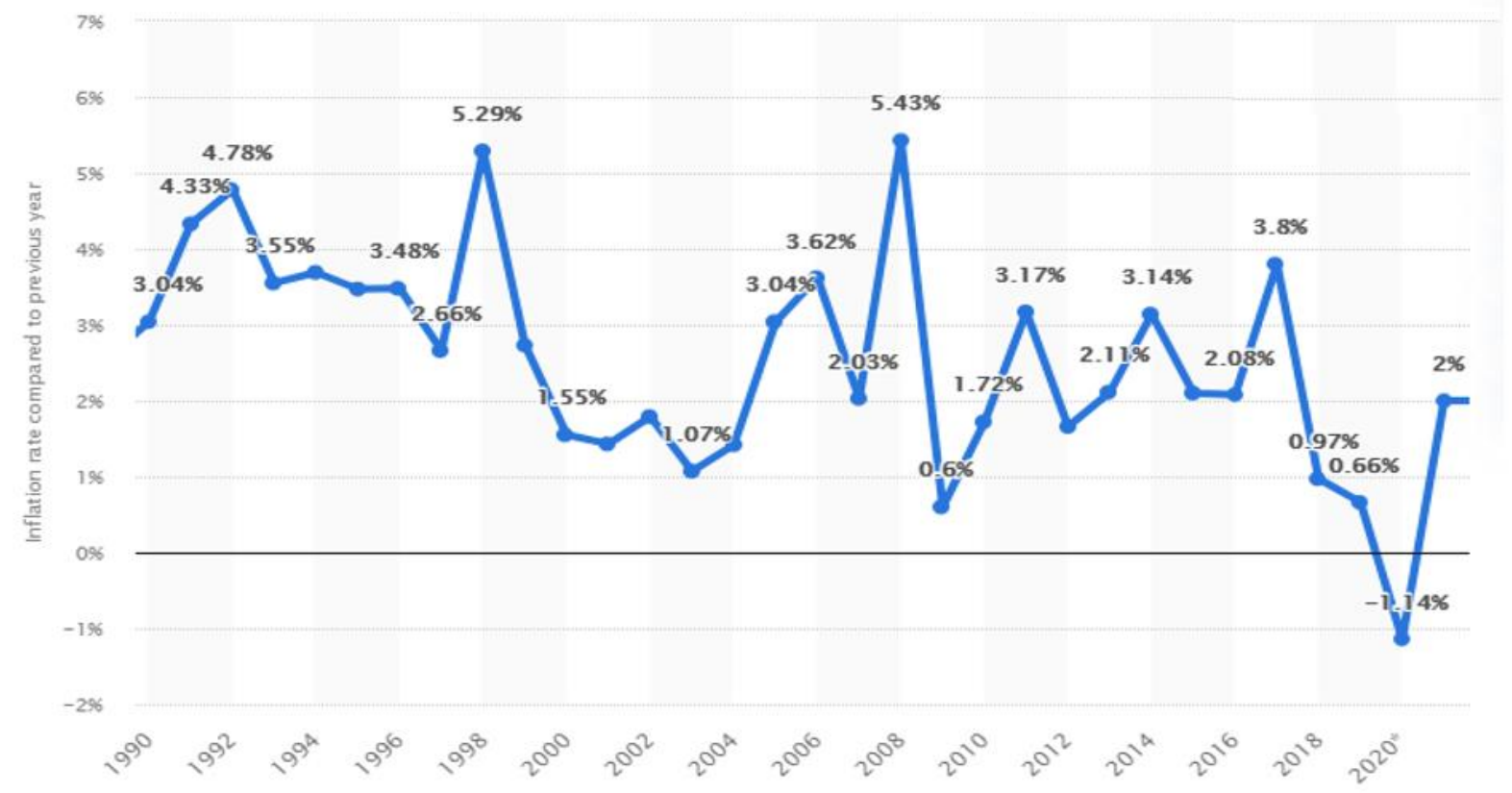

Adapted from: Statista (2021). Malaysia consumer price index from 1991 to 2020

\section{Inflation and Unemployment Rate}

The Phillips curve developed by A.W. Phillips states that the curve is an economic concept in which inflation and unemployment have a stable and reverse relationship (Reinbold \& Wen, 2020). As the economy is growing, the level of unemployment decreases, resulting increase in inflation is what this theory claims. However, the unemployment rate continued to rise from 1983 to 1987, reaching an all-time high of 8.7 per cent in 1987. Despite that, inflation continues to drop from 5 per cent to a recent paper (Hooper et al., 2019).

\section{Inflation and Economic Growth}

Inflation has long been a source of debate about whether it is beneficial or destructive to economic growth (Aziz, 2016). The correlation between inflation and economic growth is a contentious and favourite topic for macroeconomic debates among macroeconomists, policymakers and monetary authorities worldwide.

Furthermore, previous hypotheses and research on the correspondence between inflation and economic growth have revealed that there could be a negative relationship, a positive relationship or at the very least be no relationship at all between these two variables (Majumder, 2016). According to structuralists, inflation may have a positive impact on economic growth, while according to monetarists, inflation could bring a negative effect on economic growth (Mamo, 2012).

\section{Inflation and Government Expenditure}

The relation between inflation and government expenditure has remained debatable. However, a rise in aggregate demand (AD) is likely due to increased government expenditure 
(Pettinger, 2019). Therefore, this can cause an impact on supply and lead to soaring growth in the short term. Despite that, the inflation rate in Malaysia is still under control, $0.66 \%$ in 2019 and $0.97 \%$ in 2018, a slight decrease from the previous year.

\section{Inflation and Exchange Rate}

Inflation and currency value are adversely correlated since countries with lower inflation have higher currency values (Ramasamy \& Abar, 2015). Furthermore, depending on the economic condition in the foreign market, the currency could cause volatility (Mohd et al., 2016). Thus, as the exchange rate falls, the money loses value in comparison to other currencies. In addition, changes in exchange rates can affect production costs and imported product prices, which will be affected by changes in exchange rates. As a result, it is possible to assume that exchange rate and inflation have a similar relationship (Monfared \& Akin, 2017).

Hence, this study is essential in identifying and providing a detailed analysis of factors that contribute to inflation and its impact on consumers in Malaysia, which could then be utilized for sound economic planning. Therefore, this research will concentrate on the independent variables of the unemployment rate, exchange rate, economic growth and government expenditure which will contribute to the increase in inflation (CPI) in Malaysia by using time series data from 1991 to 2020.

\section{Purpose of The Study}

The purpose of this research is to discover the factors that influence Malaysia's inflation rate. Hence, the study is primarily interested in the independent variables of the unemployment rate, economic growth, government expenditure and exchange rate. Previous research conducted by Islam et al (2017) has focused on the exchange rate, unemployment rate and money supply on the inflation rate. In addition, the study by Ramayah (2016) only focused on money supply, oil and price and the exchange rate. Next, Munir and Mansur (2009) focused on economic growth while Furouka (2007) only focused on the unemployment rate.

Furuoka (2007) examined the correlation between inflation and unemployment based on past studies. He also examined the link using Malaysian time-series data from 1973 to 2004. Furthermore, the Philips Curve was high proof inflation in the United States during 1960, and the unemployment event will occur in the following decades (Ramayah, 2016). Aside from that, Cheng and Tan (2002) used time-series data from 1973 to 1996 to investigate inflation in Malaysia. However, according to those studies, the time series data they utilise is obsolete, and no new research has been conducted in Malaysia for the period 1991 to 2020. As a result, the focus of this study will be on whether these factors have an impact on Malaysia's inflation rate from 1991 to 2020.

\section{Literature Review}

Inflation is defined as a steady increase in the price of goods and services due to a decrease in the value of the currency (Mun et al., 2017). As prices rise from low to high levels, it results in the falling of dollar value and the buying power decreases from being able to purchase a lot to buy a few (Byers et al., 2004). Inflation is measured using Consumer Price Index (CPI) data over a period of time to assess price changes associated with the cost of living. Therefore, $\mathrm{CPI}$ will tell policymakers and researchers what has happened to the value of money that the country hold as inflationary rates are known to cause a slew of problems for the economy. There are some factors that contribute to the increase and decrease of inflation such as money supply, exchange rate, unemployment rate, general budget deficit and economic 
growth. Many individuals may have been lulled into thinking that inflation is an issue of the past and that the inflation rate has been low since the global financial crisis of 2008. Since 1991, Malaysia has enjoyed low and constant inflation, with the exception of the Asian Crisis, when inflation rose to over 5\% (Crichton, 2006). However, the highest inflation rate was reported in 1974 with $17.34 \%$ of the inflation rate. With the recent spike in food prices, it is becoming increasingly difficult for Malaysian consumers to manage their daily finances (Mun et al., 2017).

William Philips has proposed that unemployment and inflation had a trade-off relationship in the United Kingdom in 1958. Since then, the "Phillips curve" has been used to describe the reciprocal relationship between unemployment and inflation. As a result, the Phillips curve has captivated the interest of many scholars to use his theory in their studies. Thus, the concept of the Philips curve has been extensively adopted and is a key concern by policymakers and central banks (Islam et al., 2017).

Furthermore, another study adds to the empirical evidence for the presence of the Phillips curve in Malaysia. According to Furouka (2007), using annual data from 1973 to 2004, there is a relationship between inflation rate and unemployment rates in Malaysia. Other prior research by Kogid et al (2011); Tang and Lean (2007) had the same viewpoint as Furouka (2007), discovering a correlation between inflation and Malaysia's unemployment rate. Examining the presence of the Phillips curve in other economies, on the other hand, may be instructive because different socioeconomic backgrounds of countries can influence the relationship between unemployment and inflation rates. For example, according to previous research conducted by Alisa (2015), the Philips curve does not exist in Russia.

Munir and Mansur (2009) demonstrate that the inflation rate's impact on economic development is negative in high inflation environments and can also be positive and more significant in low inflation environments. It implies that both high and low levels of inflation can have a beneficial and harmful impact on the economy; nonetheless, a low level of the inflation rate is widely acknowledged in macroeconomics as a crucial tool for promoting economic growth. However, the result by Naseri and Zada (2013) clearly analyse the relationship between inflation and economic growth using the data from 1970 to 2011 in Malaysia. In contrast to the commonly held assumption that inflation is a challenge to economic development, the findings revealed that inflation has a significant positive impact on Malaysia's economic growth. According to this, inflation drives individuals to seek interest in purchasing capital assets to ensure that their money's value remains stable.

Mehrara \& Sujoudi (2015) examined the relationship between inflation, government expenditure and money supply in Iran using time series from 1959 to 2010. The researchers utilized the Bayesian econometric approach in the analysis and the results revealed that the variables have no significant impact on the country's inflation rate. Furthermore, the previous study by Shaari, Tunku \& Razali (2018), which examined panel data from 1986 to 2014, reached the same conclusion indicating that government spending has no significant impact on inflation. Thus, it is possible to dismiss the commonly recognized hypothesis that government spending positively impacts inflation. This is attributed to the large number of government subsidies allocated to products and services, which reduced production costs and changed the aggregate supply curve to the right, potentially leading government spending to have a negative impact on inflation.

Based on the previous study by Madesha, Wellington, Clainos and James (2013), inflation and the exchange rate have a causal relationship. They emphasized that the country's exchange rate policy determines the impact of exchange rate on inflation. Therefore, the change in the 
exchange rate, from the other side, will have a direct impact on the overall economy. Moreover, the researcher explains that there has a long-term relationship between inflation and the exchange rate. When a local currency depreciates, the cost of imports rises, resulting in higher production costs and prices therefore, the number of items or commodities will also rise.

\section{Methodology}

The type of investigation for this study is a correctional study. The correctional research aims to determine the extent of essential variables in a relationship between two variables or more variables are associated using quantitative data. Consequently, this study is to find out the influence of selected variables on Malaysia's inflation rate. Hence, this degree of relation is express as a correlation coefficient. Simple random sampling is used in this study, which allows a clear statistical inference about the whole population. Researchers would like to see results that are representative of the entire population. Therefore, each person in the large population set has an equal probability of being selected, resulting in a balanced subset with the best probability of accurately representing the wider group.

Moreover, the data for this study were collected during 30 years, from 1991 to 2020 . For this study, a total of 30 years of observations were used for each variable. The population in this research focuses on the percent of GDP, exchange rate, and employment rate measured as the total population in Malaysia. These were chosen as the indicators because of their high accuracy in representing the most commonly used measure of inflation. In addition, it looked into the factors that affect Malaysia's inflation rate.

\section{Data Collection Method}

This research paper concentrates on secondary quantitative data. The dependent variable in this study is the inflation rate, while the independent variables are economic growth, unemployment rate, exchange rate, and government expenditure. This paper makes use of time-series results. The study's sample consists of findings of each independent and dependent variable yearly from 1991 to 2020. The annual data collected are from World Bank, Thomson Reuters DataStream and Knoema, and the software used for the data analysis is EViews version $11 \mathrm{SV}$. This software assists in the interpretation of data obtained in order to accurately construct a statistical relationship between the dependent and independent variables. The test that will be carried out in this research is the regression test whereby Ordinary Least Square (OLS) is used to find the significance between dependent and independent variables.

\section{Theoretical Framework}

Figure 2 illustrates the relationship between inflation and the independent variables that influence the inflation rate in Malaysia, namely, government expenditure, unemployment rate, economic growth, and exchange rate. 
Independent Variables

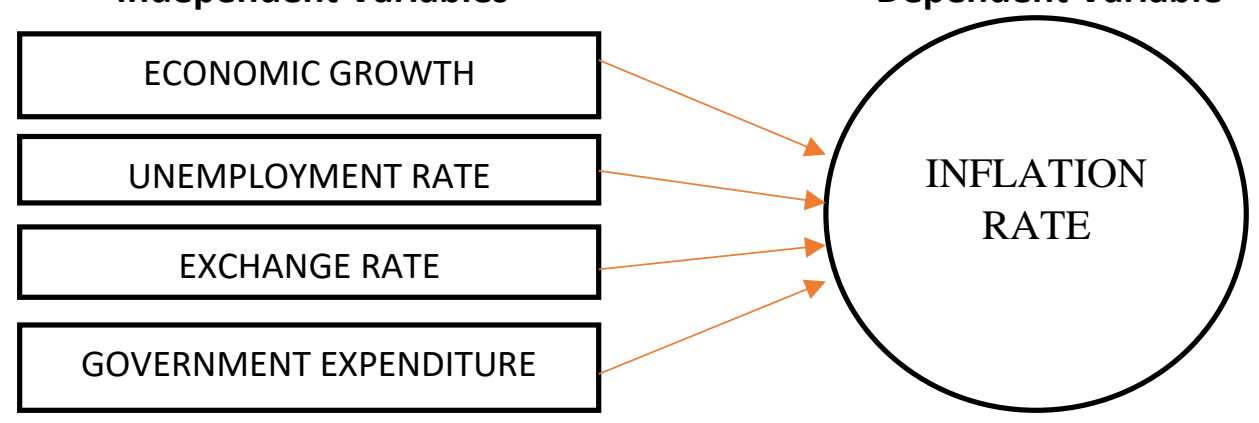

Figure 2

\begin{tabular}{|l|c|c|c|l|}
\hline Variable & Coefficient & Std. Error & P-value & Results \\
\hline $\begin{array}{l}\text { Economic } \\
\text { Growth }\end{array}$ & 11.48339 & 0.893759 & 0.5928 & $\begin{array}{l}\text { Not significant; do not reject null } \\
\text { hypothesis (H0) }\end{array}$ \\
\hline $\begin{array}{l}\text { Government } \\
\text { Expenditure }\end{array}$ & -0.014931 & 0.027562 & 0.0129 & Significant; reject null hypothesis (H0) \\
\hline $\begin{array}{l}\text { Unemployment } \\
\text { Rate }\end{array}$ & 0.533762 & 0.199436 & 0.0068 & Significant; reject null hypothesis (H0) \\
\hline Exchange Rate & -0.450878 & 0.152751 & 0.0000 & Significant; reject null hypothesis (H0) \\
\hline
\end{tabular}

\section{Results of the Study}

Table 1: Ordinary Least Squares (OLS) results.

R-squared: 0.836761

Adjusted R-squared: 0.810643

F-statistic 32.03753

Prob (F-statistic): 0.000000

\section{Regression Equation}

$L n C P I=11.48339-0.014931 L n G D P+0.533762 L n G E-0.450878 L n U R-1.682138 L n E R$
$(0.027562)$
(0.199436)
$(0.152751)$
$(0.165177)$

The $\mathrm{R}^{2}$ value of 0.836761 implies that $83.68 \%$ of the dependent variable (CPI) variation is explained by the independent variables namely economic growth, unemployment rate, government expenditure and exchange rate while other factors are not included in the study account for the remaining $16.32 \%$. Moreover, the $p$-value of the F-statistic is 0.0000 is used to test the overall significance of the regression model; thus, researchers can reject the null hypothesis. According to the results from Table 1, at a 95\% confidence interval, government expenditure, exchange rate and unemployment rate are significant independent variables in forecasting inflation.

The government expenditure indicates a positive and significant relationship with inflation (CPI). It shows that a rise in one percent of government expenditures will rise the Consumer 
Price Index by 0.533762 . This discovery is consistent with the finding from previous researchers that a rise in government expenditure does lead to inflation. If the government expenditure increases, it will almost certainly increase the aggregate demand (AD). Therefore, this can result in a faster growth rate in the short term and cause inflation.

The unemployment rate has a significant and negative relationship with inflation. The result shows 0.0068 at a $95 \%$ confidence interval and a negative 0.450878 coefficient. Analysing the beta coefficient of negative 0.450878 for the unemployment rate signifies that for every $1 \%$ increase in the unemployment rate, the CPI will decline by 0.450878 . This finding is congruent with empirical findings from previous journal articles. Therefore, this result offered additional practical support and encouraged a closure look the existence of the Philips curve in Malaysia for the time series between 1991 to 2020.

The exchange rate has a negative and statically significant relationship with inflation. The variable has a beta coefficient of - 1.682138. Holding all other variables constant, the Consumer Price Index will fall by 2.212621 points for every MYR increase against the USD, indicating the depreciation of the Malaysian Ringgit. As a result, this is consistent with the previous journal article, which claimed that the exchange rate is the most significant factor that influences the rising of inflation in Malaysia.

At a $95 \%$ confidence interval, the $p$-value for economic growth (GDP) is 0.5928 . It shows that the economic growth is insignificant as the level of $p$-value is more than 0.05 and has a negative/inverse relationship with inflation (CPI). With a beta coefficient of negative 0.014931 for the LnGDP, a rise in one percent of GDP causes inflation (CPI) to fall by 0.014931 points. However, the results are contradicted with the study in the past stated that economic growth does indeed lead to inflation.

\section{Conclusion}

In conclusion, this study attempts to find the relationship between the unemployment rate (UR), economic growth (GDP), government expenditure (GE), and exchange rate (ER) with inflation in Malaysia has been examined with the annual data covering 1991 to 2020. This study used the Ordinary Least Squares (OLS) method to investigate the relationship between the variables and inflation. The study's findings showed that exchange rate, unemployment rate, and economic growth were negative relationships while government expenditure has a positive relationship with inflation. Overall, despite the data sets' imperfection in meeting the classical assumption criteria and the hypotheses, the outcomes of the OLS test were found to be quite promising.

The exchange rate, unemployment rate, and government expenditure displayed significance in forecasting inflation in Malaysia. The finding is coherent with the study of Cheng and Tan (2002); Aurangzeb (2012) that government expenditure, exchange rate, and unemployment rate have a significant impact on inflation. Moreover, according to the data, the exchange rate is the most prominent element in explaining inflation in Malaysia since it is statistically significant. This is accordant with the economic report of Bank Negara Malaysia (2018) that it is empirically evident that the exchange rate is the most significant factor behind the rising of inflation in Malaysia. Based on the first quarter Malaysia Economic Outlook report 2021, because of geopolitical uncertainty, decreasing commodity prices, and the fast escalation of 
the Covid-19 pandemic, the ringgit is quickly depreciating against the US dollar. As the ringgit is depreciated, it results in a lower exchange rate, thus resulting in a rise in the inflation rate.

Inflation and unemployment are fundamental phenomena in the economy and are seen as devastating impacts on the economy. In the study period of 1991 to 2020, the unemployment rates are increasing, and the capability of the population in Malaysia to obtain work remains a serious issue. So, based on the research material, there is no denying that there is a relationship between inflation and unemployment rate. Therefore, the objective to find the existence of Philips Curve in Malaysia is achieved as the unemployment rate and inflation have a negative and significant impact on inflation. Furthermore, it is consistent with the Philips Curve theory, which states that the higher the inflation rate, the lower the unemployment, and vice versa (Alisa, 2015). The previous research conducted by Furouka (2007); Tang and Lean (2007) provides additional empirical support to the existence of the Philips Curve in Malaysia inflation rises when the unemployment rate falls, and vice versa.

Furthermore, the findings in the study were found that economic growth does not have a significant relationship with inflation, and the results are coherent with the study conducted by Kasidi (2017). Based on the previous literature review, most of the studies conducted on the determinants of inflation using economic growth as an independent variable shows that it has a significant relationship with inflation. Only a few studies and journals came out with insignificant relationships between the independent and dependent variables; however, the tests used in the research are different. Furthermore, researchers did not provide the specific reasoning behind the insignificant relationship between the variables in the research papers. Thus, researchers are struggling to explain why economic growth has an insignificant relationship with inflation.

Given the significance of these "evil" macroeconomic factors to Malaysia's economic stability, an additional relevant study should be conducted frequently. This is to guarantee that future economic policy planning runs smoothly and effectively and sustain economic development (Kogid et al., 2011). Furthermore, to control inflation, the government should be tightening the monetary policy. In developed countries, monetary policy is a crucial policy used for reducing inflation and stabilising economic activity. Moreover, in the previous study conducted by Islam et al., (2017), Malaysia's government can use monetary policy to counter Malaysia's high inflation. One option is through credit regulation, in which Malaysia's central bank must try to control the quantity and quality of debt in the country. It can do so by raising bank rates, selling securities on the open market, increasing the reserve ratio, and controlling consumer lending if the central bank raises interest rates. Higher interest rates make borrowing more costly and saving more appealing. As a result, consumer spending and investment will rise slower, which helps in reducing inflation.

\section{References}

Alisa, M. (2015). The Relationship between Inflation and Unemployment: A Theoretical Discussion about the Philips Curve. Journal of International Business and Economics, 3(2), 89-97. https://doi.org/10.15640/jibe.v3n2a7

Arinze, P., (2011). The Impact of Oil Price on the Nigerian Economy. Journal of Research in National Development, vol. 9, no. 1. 
Aurangzeb. (2012). Factors Affecting the Trade Balance in Pakistan. Economics and Finance Review Vol. 1(11) pp.25 - 30.

Aziz, H. T. (2016). the Impact of Inflation on Economic Growth: Evidence of Malaysia From the Period 1970-2014 the Impact of Inflation on Economic Growth: Evidence of Malaysia From the Period 1970-2014. 75.

Byers, S., Cutler, H., \& Davies, S. (2004). Estimating costs and benefits of economic growth: A CGE-based study of tax incentives in a rapidly growing region. Journal of Regional Analysis and Policy, 34(2), 1-20.

Cheng, M. Y., \& Tan, H. B. (2002). Inflation in Malaysia. International Journal of Social Economics, 29(5), 411-425. https://doi.org/10.1108/03068290210423532

Crichton, D. R. (2006). Inflation Dynamics in Malaysia. Inflation Dynamics in Malaysia, 1- 31.

Economic Outlook. (2021). Malaysia's Economic Outlook Report 2021. Economic outlook. Flexo, 26(6), 16

Egilsson, J. H. (2020). How raising interest rates can cause inflation and currency depreciation. Journal of Applied Economics, 23(1), 450-468.

https://doi.org/10.1080/15140326.2020.1795526

Furuoka, F. (2007). Does the "Phillips curve" really exist? New empirical evidence from Malaysia. Economics Bulletin, 5(16), 1-14.

Hooper, P., Mishkin, F. S., Harris, E., Hamilton, J., Kashyap, A., Klachkin, O., Mann, C., Roberts, J., Hooper, P., \& Bank, D. (2019). Prospects for Inflation in a High-Pressure Economy

Islam, R., Abdul Ghani, A. B., Mahyudin, E., \& Manickam, N. (2017). Determinants of Factors that Affecting Inflation in Malaysia. International Journal of Economics and Financial Issues, 7(2), 355-364.

Kasidi, F. (2017). Impact of Inflation on Economic Growth. 3(4), 18

Kogid, M., Asid, R., Mulok, D., Lily, J., \& Loganathan, N. (2011). Inflation-Unemployment Trade-Off relationship in Malaysia. Asian Journal of Business and Management Sciences, 1(1), 100-108.

Madesha, W., Chidoko, C., \& Zivanomoyo, J. (2013). Empirical Test of the Relationship Between Exchange Rate and Inflation in Zimbabwe. 4(1), 52-59.

Majumder, S. C. (2016). Inflation and Its Impacts on Economic Growth of Bangladesh. American Journal of Marketing Research, 2(1), 17-26

Mamo, F. T. (2012). Economic Growth and Inflation A panel data analysis. Economics, 1-44.

Maryam, H. J., Hashim, M. J., Osman, I., Nura, \&, \& Elias, L. (2014). the Determinants of Inflation in Malaysia. August 2014.

Mehrara, M., \& Sujoudi, A. (2015). The Relationship between Money, Government Spending and Inflation in the Iranian Economy. International Letters of Social and Humanistic Sciences, 51, 89-94. https://doi.org/10.18052/www.scipress.com/ilshs.51.89

Mohd, W., Abdoh, Y. M., Hafizha, N., Yusuf, M., Azreen, S., Zulkifli, M., Bulot, N., \& Ibrahim, J. (2016). Macroeconomic Factors That Influence Exchange Rate Fluctuation in ASEAN Countries. International Academic Research Journal of Social Science, 2(1), 89-94.

Monfared, S. S., \& Akın, F. (2017). the Relationship Between Exchage Rates and Inflation: The Case of Iran. European Journal of Sustainable Development, 6(4), 329-340. https://doi.org/10.14207/ejsd.2017.v6n4p329

Mun, J. W. Y., Teng, L. Y., Yi, L. H., \& Jie, T. J. (2017). Effect of Macroeconomic Variables. August, 15-59.

Munir, Q., \& Mansur, K. (2009). Non-linearity between inflation rate and GDP growth in Malaysia. Economics Bulletin, 29(3), 1551-1565. 
Naseri, M., \& Zada, N. (2013). Effect of Inflation on Economic Growth: Evidence from Malaysia. International Centre for Education in Islamic Finance, April 2013, 14.

Ramasamy, R., \& Abar, S. K. (2015). Influence of Macroeconomic Variables on Exchange Rates. Journal of Economics, Business and Management, 3(2), 276-281. https://doi.org/10.7763/joebm.2015.v3.194

Ramayah, T. E. M. (2016). A Contemporary Business Journal the Determinants of Inflation: An ASEAN Perspective. 6(August), 49-72.

Reinbold, B., \& Wen, Y. (2020). Is the phillips curve still alive? Federal Reserve Bank of St. Louis Review, 102(2), 121-144. https://doi.org/10.20955/r.102.121-44

Shaari, M. S., Ahmad, T. S., \& Razali, R. (2018). Tourism Led-Inflation: A case of Malaysia. MATEC Web of Conferences, 150, 1-6. https://doi.org/10.1051/matecconf/201815006026

Stability, F., \& Report, P. S. (2019). Bank Negara Malaysia 2018 Annual Report \&Amp; Financial Stability and Payment Systems Report. March. http://www.bnm.gov.my/documents/2019/2018_AR_FSPSR_slides.pdf

Tang, C. F., \& Lean, H. H. (2007). Is the Phillips curve stable for Malaysia? New empirical evidence. Malaysian Journal of Economic Studies, 44(2), 95-105.

Pettinger, T. (2019). Causes of inflation. https://www.economicshelp.org/macroeconomics/inflation/causes-inflation/ 